The Lunacy Commissioners have distinctly opposed the treatment of chronic lunatics and dements except in regulated establishments, because they know that the weakest class of bumanity can only get true attention from disciplined philanthropy. Be it understood that I am not advocating special asylums with all the elaborate paraphernalia associated with them in the minds of alienists, but I do insist upon places of refuge for these unfortunate persons, be they "asylums" or be they "workhouses," where that care can be bestowed which is impossible in the homes of the London poor.

In most asylums there are young men and women slightly imbecile only, the usual " helpers" in the wards, who work well, but yet are unable alone to fight the world's battle. Now here is an outlet for charity. If some benevolent persons would but take these persons into their houses and employ them, they would have good and tractable servants at cheap wages, requiring only such protection as a wellregulated household can afford. During the last few months $I$ have found homes for several in this way who must otherwise have remained incarcerated. If the asylum boards were to issue advertisements that the friends of patients undertaking to attend to them at home would be supplemented by a weekly aid, some would doubtless respond to the call; but, I fear, few, and the extra expense to the parishes of having them looked after at home would be great. Should, moreover, any instances of neglect occur, the public would more than ever insist on special buildings.

London is so large, so all-absorbing, so full of vice, drunkenness, and depravity, so different in all its life from country existence, that it is impossible to argue from one to the other; and whilst thinking that Dr. Williams may be able to keep the Hayward's Heath Asylum to its present limits, I fear that the cry in London will for some time be "Build, build!"

I am, Sir, yours obediently,

T. Claye Shaw, M.D., M.R.C.P.,

Lecturer on Mental Science, St. Bartholomew's Hospital, and Medical Superintendent, Metropolitan Asylum,

Dec. 18th, 1871 Leavesden.

\section{THE MEDICAL DECLARATION RESPECTING ALCOHOL.}

To the Editor of THE LANCET.

SIR,-I wish, with your permission, to state the reasons which have prevented me from signing the medical declaration respecting alcohol.

1. I admit that doctors have occasionally done harm to patients by injudicious prescriptions of alcohol. But I call it a great and mischievous misrepresentation to imply that the amount of drunkenness so produced bears any appreciable proportion to the total mass of intemperance. Any general or partial increase that may have taken place in the latter is, for practical purposes, to be ascribed to the increase of all kinds of extravagant habits in all classes of society, coupled with the influence, in the case of the poor, of want of education and of physical comfort in their homes.

2. To the uninstructed public, the assertion that the "dietetic value of alcohol has been immensely exaggerated" will convey a perfectly erroneous idea. It will seem to deny the alimentary character of alcohol. Now the latest researches by competent observers, on the contrary, tend strongly to the opposite conclusion.

In fact, the only unobjectionable part of the declaration is the suggestion, in which I heartily concur, that the profession should assist the Government to carry a reasonable Licence Regulation Bill, or to adopt other means of removing needless and artificial sources of temptation to excess. I am, Sir, yours faithfully,

Wimpole-street, Dec. 28th, 1871. Francis Ed. Anstie.

\section{THAMES SHIPPING INSPECTION COMMITTEE.} To the Editor of The LANCET.

SIR,-At a meeting of the sub-committee held yesterday at Guildhall, G. S. Pedler, Esq., C.C., in the chair, I was directed to forward you a history of the case detained by the Custom-house authorities at Gravesend, and to which reference was made in THE LANCET of last week. The story you have related is that a case of choleraic diarrhœe having occurred in a vessel from Copenhagen, the Customs authorities detained the ship for twelve hours, and reported it to the local authorities at Gravesend, but that no notice was taken of it by them, and that, without medical inspection, it proceeded forthwith up the river.

The facts of the case, however, are as follows:-The Norwegian schooner Amalia sailed from Waldermarsvik, Sweden, on November 12th, put in at Copenhagen, and sailed thence on November $22 n d$. Two days later a seaman named Samuel Svensden, aged twenty, complained of being sick. The captain states that he seemed to suffer from cold, pains in the body and limbs, and looseness of bowels. $\mathrm{He}$ was very short of clothing, and the weather in the Baltic during the passage was severe. The vessel arrived at Gravesend on November 27th, and was detained by the Customs from 9 A.M. to 9 P.M. on the 28 th. The case was reported to the inspector of nuisances at Gravesend as one of diarrhoea (not choleraic diarrhoea). The authorities at Gravesend did not consider a complete medical inspection necessary because a ship had on board a man with loose bowels. They therefore took no further notice of the case, and the vessel consequently was towed up the river, and ultimately entered the Millwall Docks. The man (Svensden) remained on board until December 5th, no notice whatever of the case having been given to the Poplar Board, or to its officers. On December 5th the man was removed to the Seamen's Infirmary at Greenwich, and the entry on the books of the hospital is to the effect that the disease from which he is suffering is phthisis.

The whole correspondence is before me, and I believe this to be a true unvarnished history of the case. You will allow me to state that, from my own personal knowledge, the Mayor of Gravesend is jealously watching for the very first indications of a cholera outbreak, and that few men are more alive than he is to the necessity of very prompt measures the moment they are called for. But I cannot think any advantage can possibly ensue from sensational stories being dressed up to act as levers to urge on at a greater speed the work the committee have in hand; which, though it may not be progressing at the rate some may desire (I confess that I desire myself, but then I know the difficulties), is, I believe, laying a very solid foundation fox immediate action in the case of an outbreak of cholera, and, what is more, doing all it has the power to do to prevent the introduction of the disease.

I am, Sir, your obedient servant,

C. Meymott Tidy, M.B., Hon. Secretary. Cambridge Heath, Dec. 20th, 1871.

** We insert this letter in order that the public may have an opportunity of knowing what the Thames Shipping Inspection Committee, according to their own account, are really about. If the Mayor of Gravesend, "jealously watching for the very first indications of a cholera outbreak," has the prescience to discriminate between phthisical, choleraic, typhoid, dysenteric, and other diarrboas that occur afloat, without emerging from the municipal chair or consulting his medical officer, he holds an eminently enviable position, and no "complete medical inspection" will ever be required at the entrance of the port of London. But, inasmuch as, according to our own knowledge and belief, the Committee is not "doing all it has the power to do to prevent the introduction of the disease," we recom. mend its members to study the Orders in Council dated the $29 \mathrm{th}$ day of July and 3rd of August respectively, and to take a leaf out of the book of the local authorities in the North-eastern ports of the kingdom.-ED. L.

\section{BIRMINGHAM.}

(FROM OUR OWN CORRESPONDENT.)

The Bill prepared by the Sewage Committee of the Corporation of Birmingham has been thoroughly discussed by the Town Council during the past week, and has come out of the ordeal with comparatively little alteration or amendment. The powers given under the Act are very extensive, 